\title{
Effects of tree size and park maintenance on soil seed bank of Gleditsia triacanthos, an exotic tree in urban green areas
}

\author{
Péter Csontos $^{1} \cdot$ Tibor Kalapos $^{2} \cdot$ Tito Faradhimu $^{3} \cdot$ Annamária Laborczi $^{1} \cdot$ Tamás Hardi $^{4} \cdot$ Júlia Tamás $^{5}$
}

Received: 19 December 2019 / Accepted: 9 April 2020 / Published online: 10 June 2020

(c) The Author(s) 2020

\begin{abstract}
The exotic honey locust (Gleditsia triacanthos) is often planted as ornamental tree in urban parks. In Hungary, it occasionally escapes cultivation, in other countries it has already become invasive, and thus, further spread cannot be ruled out. The production of copious long-lived seeds may contribute to its invasiveness. We investigated the soil seed bank of honey locust growing in urban parks of Budapest (Hungary). Soil samples of $1200 \mathrm{~cm}^{3}$ were taken under the canopy of 48 solitary female trees, seeds were extracted by washing, and their viability was assessed by germination test following scarification. For each tree, trunk circumference and level of park maintenance were recorded. Seed bank density varied between 0 and 500 seeds $/ \mathrm{m}^{2}$ and in 17 out of 48 cases, it exceeded $100 \mathrm{seeds} / \mathrm{m}^{2}$. Larger trees tended to form better-developed soil seed bank than smaller ones, yet the level of park maintenance has a much stronger effect: trees in neglected parks produced fivetimes higher density on average than those in perfectly managed parks (126.4 and $24.5 \mathrm{seeds} / \mathrm{m}^{2}$, respectively). For a better understanding of the species' invasion risk, detailed seed ecological studies are needed and to prevent its further spreading, a more careful treatment of its litter is recommended.
\end{abstract}

Keywords Alien tree $\cdot$ Germination test $\cdot$ Honey locust $\cdot$ Mechanical scarification $\cdot$ Soil seed bank $\cdot$ Urban parks

\section{Introduction}

Urban green areas in modern cities provide a number of ecosystem services for inhabitants such as noise reduction, water and air purification and microclimate stabilization (Bolund and Hunhammar 1999; Chiesura 2004; Bowler et al. 2010). Additionally, these areas are essential in providing

Péter Csontos

cspeter@mail.iif.hu

1 Institute for Soil Science and Agricultural Chemistry, Centre for Agricultural Research, Herman Ottó út 15, Budapest 1022, Hungary

2 Department of Plant Systematic, Ecology and Theoretical Biology, Eötvös Loránd University, Pázmány P. stny. 1/C, Budapest 1117, Hungary

3 Centre for Environmental Studies, Faculty of Natural Sciences, Eötvös Loránd University, Pázmány P. stny. 1/C, Budapest 1117, Hungary

4 Institute for Regional Studies, Centre for Economic and Regional Studies, P.O. Box 420, Győr 9002, Hungary

5 Department of Botany, Hungarian Natural History Museum, Könyves Kálmán krt. 40, Budapest 1087, Hungary recreational and aesthetic services (Brander and Koetse 2011; Buchel and Frantzeskaki 2015).

Exotic ornamental species are widely planted in urban green areas and contribute to many of the park's beneficial effects in the same way as native species do (e.g., heat wave mitigation, water retention, wind protection). In certain aspects, like in increasing the beauty of parks, these alien plants may even exceed native species (Muratet et al. 2015). However, there are many non-native plant species which originally has been introduced intentionally for ornamental purposes, later escaped from cultivation, established their self-sustaining stands and became invasive, thus threatening native biodiversity in resident (semi)natural ecosystems in the countryside (Essl 2007; Čeplová et al. 2017). Undoubtedly, invasive plants are among the prominent conservation threats and have affected biodiversity seriously throughout the world already (Richardson and Pyšek 2006; Chmura 2013; Early et al. 2016).

Honey locust (Gleditsia triacanthos) is a deciduous dioecious tree native to central North America and has been planted throughout the world-including Europe-since 1700 (Benčat 1982). In rural areas, this species is often used as hedge plant because of its sharp thorns and resistance 
to pruning. Due to its tall growth, delicate foliage turning golden in autumn, and conspicuous large seedpods staying long on the tree, honey locust is widely planted in urban green areas and parks for ornamental purposes.

From some European countries, including Hungary, honey locust was reported as sporadically occurring alien tree (Balogh et al. 2004; Pyšek et al. 2012; Glišić et al. 2014; Glogov et al. 2019). However, its recent sporadic character does not rule out that it may be seriously invasive in the future. Numerous alien species survive in its new territory in low abundance for years after its introduction (called "lag phase") before suddenly becoming invasive (Hobbs and Humphries 1995). This has already happened in some regions, especially in Argentina where honey locust becomes one of the most harmful invasive plants with great potential to continue further expanding its range (Ferreras et al. 2015; Fernandez et al. 2017). Local adaptation of plant traits, particularly those associated with seeds and seedlings, could play a key role in the process (Kudoh et al. 2007; Tognetti et al. 2019).

Honey locust produces abundant seed crop every year, and the seeds are hard-coated having a thick seed coat impermeable to water that makes the trees capable of establishing high-density soil seed bank under their canopies. The seeds can also be dispersed to large distances by birds and mammals which eat the pod for its high carbohydrate content (Blair 1990). The viability of seeds lasts long; therefore, considerable amount of seeds could accumulate in the soil especially under old trees.

The soil seed bank of alien species can be the source of unintentional spread and colonization in neighboring areas when topsoil replacement is applied during park renovation works. Regular litter removal, that includes seed pods as well, might prevent or reduce soil seed bank formation in parks. However, transport of litter to sites where it is treated (composted, incinerated or deposited to landfill) — if not carried out properly - can initiate new colonization. Therefore, human effects such as shaping the species composition and age structure of urban green areas as well as the intensity of park maintenance are vital in preventing the unwanted impact of alien species, including honey locust.

In this study, we aimed (1) to investigate soil seed bank density under the canopy of honey locust trees growing in urban green areas of Budapest; (2) to determine the effect of tree size on the soil seed bank; and (3) to clarify the influence of park maintenance intensity on the development of soil seed bank under the canopy of honey locust trees. It was hypothesized that larger trees tend to have better-developed soil seed bank under the canopy compared to smaller trees, and soil seed bank will be less developed in well-managed parks than in neglected ones due to the regular removal of fallen seedpods during park maintenance.

\section{Materials and methods}

To investigate the soil seed bank under ornamental honey locust trees, a total of 48 solitary female individuals growing in parks or other urban green areas (collectively named parks hereafter) were selected across Budapest (Fig. 1). Doubletrunk trees and those having damaged crown were excluded. Exact GPS coordinates of the selected trees are listed in "Appendix 1".

The honey locust trees sampled in parks were divided into three size categories as follows: (1) small trees (trunk circumference is lower than $0.60 \mathrm{~m}$ ); (2) medium-sized trees (trunk circumference is between 0.60 and $1.20 \mathrm{~m}$ ); and (3) big trees (trunk circumference is larger than $1.20 \mathrm{~m}$ ). Tree trunk circumference was measured at breast height with $0.01 \mathrm{~m}$ accuracy by using a $1.5 \mathrm{~m}$ tape measure.

According to park maintenance intensity, three different levels were distinguished: (A) perfectly maintained parkthe condition of urban parks which are very well treated, for instance, fallen leaf litter, branches and seed pods regularly removed, lawn (if present) cut short, etc.; (B) moderately maintained parks - the urban parks receive the above treatments irregularly thus some litter, fruits and hay may accumulate for shorter periods; (C) neglected parks - abandoned parks or other urban green areas without maintenance resulting in the accumulation of litter and seeds from woody and herbaceous plants. Each park was classified into one of these three categories based on their appearance at the time of the visit. We are aware that the above classification of parks includes some uncertainties because maintenance intensity of certain parks might have changed through time. The combination of tree size and maintenance intensity resulted in nine categories altogether. The number of sampled trees in each category is listed in Table 1.

For soil seed bank studies, $5 \mathrm{~cm}$ deep soil cores were cut by using a metal corer of $80 \mathrm{~cm}^{2}$ surface area, in three replicates, under the canopy of each tree specimen. The three sampling points were located approximately $1.5 \mathrm{~m}$ from the trunk base in East, South and West directions, respectively. The three soil cores were merged and kept in a labeled plastic bag thus forming a soil sample of $1200 \mathrm{~cm}^{3}$ which satisfies the minimum sampling volume requirement according to Roberts (1981). Soil sampling was completed from July 2018 to October 2018. Following sampling, holes on the surface were filled with soil from nearby to restore plain ground. Soil samples were transported to laboratory in the Eötvös Loránd University, Budapest, and kept in dark and cool place until processing.

Between October 2018 and November 2018, soil samples were washed and sieved using a mesh size of $3.15 \mathrm{~mm}$, and then all material retained on this mesh was inspected for seeds. Seeds of honey locusts were extracted by hand 


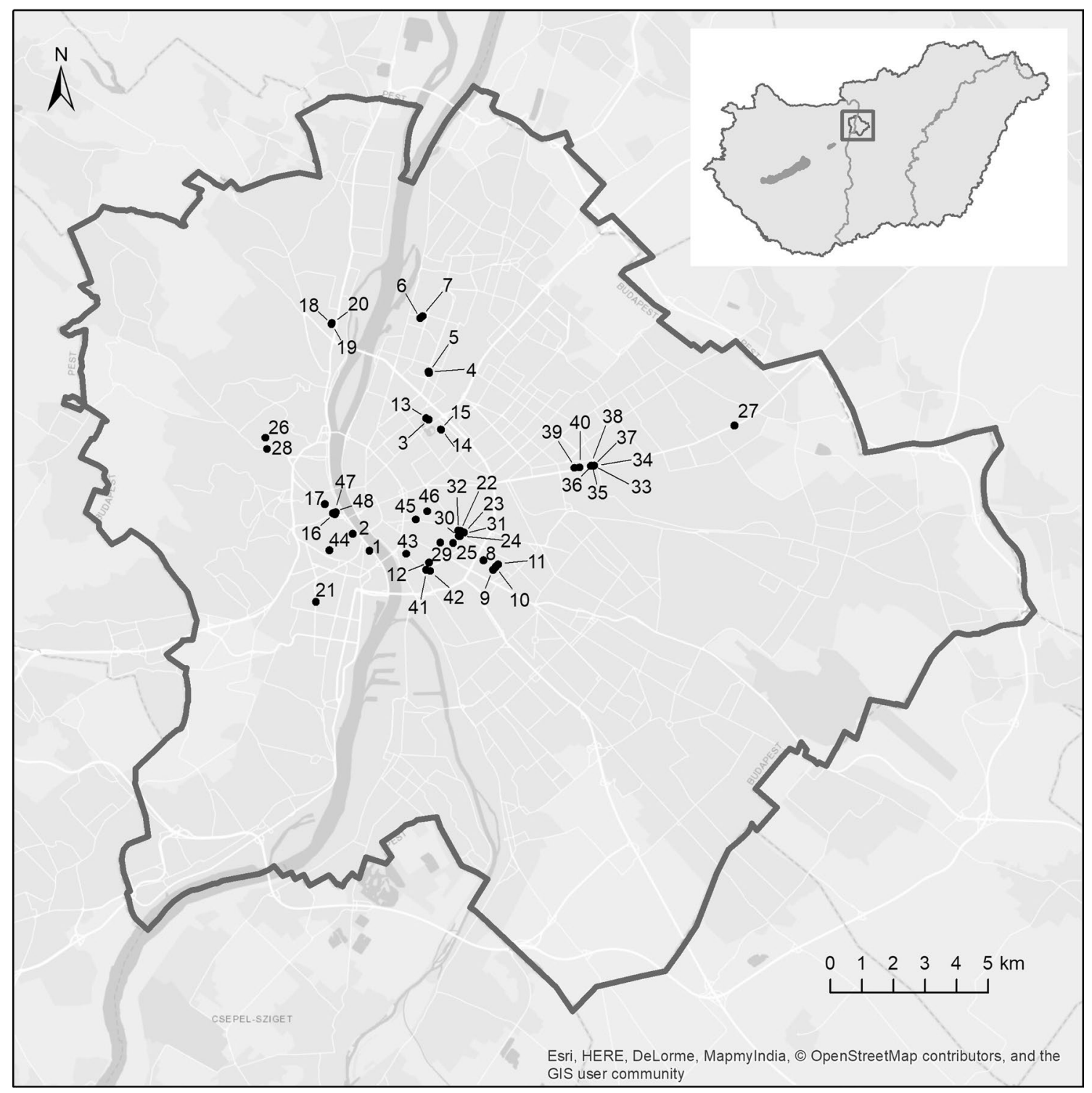

Fig. 1 Position of honey locust trees sampled for their soil seed bank in Budapest, Hungary

Table 1 Number of honey locust trees sampled in parks of Budapest, Hungary, according to the tree size and park maintenance categories distinguished

\begin{tabular}{|c|c|c|c|}
\hline \multirow{2}{*}{$\begin{array}{l}\text { Park maintenance } \\
\text { type }\end{array}$} & \multicolumn{3}{|l|}{ Tree size } \\
\hline & $\begin{array}{l}\text { Small } \\
\text { cf: }<0.60 \mathrm{~m}\end{array}$ & $\begin{array}{l}\text { Medium } \\
\text { cf: } 0.60- \\
1.20 \mathrm{~m}\end{array}$ & $\begin{array}{l}\text { Big } \\
\mathrm{cf}:>1.20 \mathrm{~m}\end{array}$ \\
\hline Perfect & 5 & 5 & 7 \\
\hline Moderate & 5 & 5 & 5 \\
\hline Neglected & 5 & 6 & 5 \\
\hline
\end{tabular}

cf, trunk circumference at breast height from this material and were put to viability test. Seed viability was assessed by germination test under room temperature (around $21{ }^{\circ} \mathrm{C}$ ). Prior to germination test, seeds were mechanically scarified to break physical dormancy by using a plier to cut a small opening on the seed coat without damaging the embryo inside (Strydom et al. 2017) and were sterilized in 5\% sodium hypochlorite solution for $10 \mathrm{~min}$. Following sterilization seeds were washed thoroughly with running tap water. For the germination test, seeds were placed into Petri dishes ( $9 \mathrm{~cm}$ diameter) on top of filter paper and moistened with tap water as necessary. Petri dishes containing the seeds were placed into a germination room receiving natural light. After 5 days, the result of germination tests was evaluated. Seeds were considered germinated if the radicle emerged from the seed and had reached 
at least $2 \mathrm{~mm}$ length. Seeds that imbibed but did not produce a radicle were determined as dead seeds. Seeds remained hard were again mechanically scarified and inspected for an additional 5-day period. In order to obtain values comparable to other studies, seed densities were expressed for $1 \mathrm{~m}^{2}$ surface area.

For statistical comparisons of soil seed bank densities of different tree size and park maintenance categories, nonparametric tests were used because data did not meet the normality and homoscedasticity assumptions of parametric tests'. Group medians were compared by the means of Kruskal-Wallis test followed by Dunn's post hoc test for multiple comparisons. The relationship between seed bank density and tree trunk circumference was studied by using least-square linear regression. For each statistical test, the significance level was $P<0.05$. Statistical analyses were conducted by using the GraphPad InStat (1998) version 3.06 software.

\section{Results}

From the soil samples taken from urban parks under canopies of 48 honey locust tree specimens, altogether 128 seeds were extracted. Following mechanical scarification, 123 seeds germinated, indicating that $96.1 \%$ of the seeds were viable and thus can be considered as constituents of the soil seed bank ("Appendix 1").

In perfectly maintained parks, increasing tree size was associated with slightly higher soil seed bank densities: $23.8 \mathrm{seeds} / \mathrm{m}^{2}$ were encountered for big trees, while only $8.3 \mathrm{seeds} / \mathrm{m}^{2}$ for medium-sized ones (mean values). Soil seed bank was completely absent under small trees. However, the increasing trend of seed bank toward larger trees was not supported by Kruskal-Wallis test due to relatively high standard deviations (Fig. 2a).

For neglected parks, much higher seed densities occurred in each tree size category. Gradually improved soil seed banks were found from small trees (125.0 seeds/ $\left.\mathrm{m}^{2}\right)$ through medium-sized trees $\left(256.9\right.$ seeds $\left./ \mathrm{m}^{2}\right)$ to big ones (366.6 seeds $/ \mathrm{m}^{2}$ ), with significant differences between small tree and big tree categories (Median(Me) small: $_{124.98,}$ $\mathrm{Me}_{\text {big }}: 374.94$, Mean rank difference(MRD): $9.30, P<0.01$ ) (Fig. 2b).

In moderately maintained parks, there was no significant difference between tree size categories according to seed density in the soil. Even a tendency could not be figured out. Nevertheless, in this comparison, medium-sized trees had the highest number of seeds in the soil $\left(133.3\right.$ seeds $\left./ \mathrm{m}^{2}\right)$ (“Appendix 2").

Park maintenance intensity resulted in clear and consistent trends for soil seed bank densities in each tree size category. For small trees, the largest soil seed bank was found

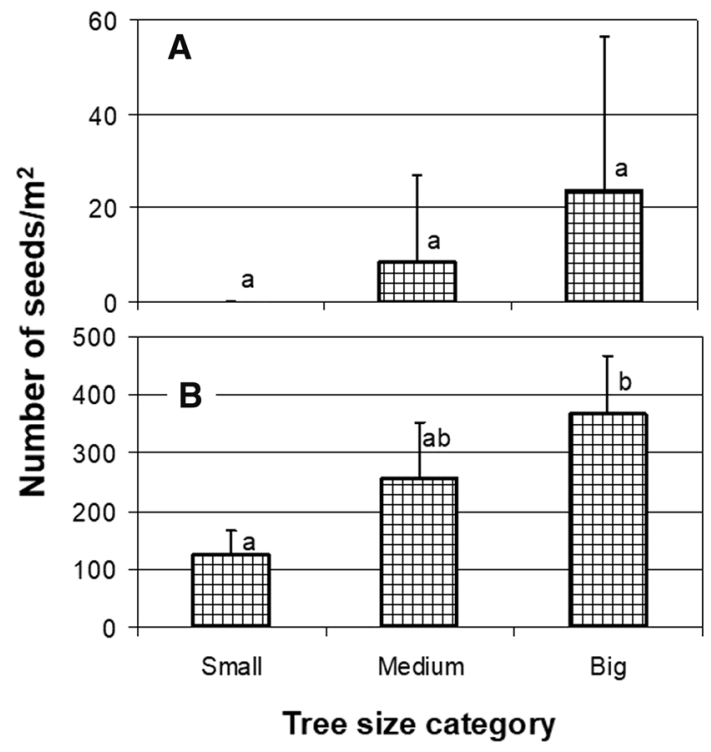

Fig. 2 The mean density of soil seed bank under different size categories of honey locust trees for perfectly maintained (a) and neglected (b) parks in Budapest, Hungary. Whiskers show + $1 \mathrm{SD}$, different letters above columns indicate statistical group membership

in neglected parks $\left(125.0\right.$ seeds $\left./ \mathrm{m}^{2}\right)$ followed by moderately maintained parks $\left(16.6\right.$ seeds $\left./ \mathrm{m}^{2}\right)$, and there was no soil seed bank at all in perfectly maintained urban parks (Fig. 3a). The increasing value of seed bank density parallel to the increasing rate of park abandonment was statistically supported, as there were significant differences between groups of perfect versus neglected $\left(\mathrm{Me}_{\text {perfect }}: 0.0, \mathrm{Me}_{\text {neglect }}: 124.98\right.$, MRD: $8.50, P<0.01)$ and moderate versus neglected park maintenance types $\left(\mathrm{Me}_{\text {moderate }}: 0.0, \mathrm{Me}_{\text {neglect }}: 124.98, \mathrm{MRD}\right.$ : 6.50, $P<0.05$ ).

Considering the medium-sized tree category, also the specimens growing in neglected parks had the highest density of soil seed bank (256.9 seeds $/ \mathrm{m}^{2}$ ) under their canopy. For moderately maintained parks, seed bank density was 133.3 seeds $/ \mathrm{m}^{2}$, followed by perfectly maintained parks where only 8.3 seeds $/ \mathrm{m}^{2}$ was found (Fig. 3b). Average seed density of the moderate treatment category showed no statistically significant difference with the neighboring groups due to the high standard deviation $(\mathrm{SD}=119.3)$. However, seed bank density of the neglected group was significantly higher than seed bank density of the perfectly maintained parks $\left(\mathrm{Me}_{\text {neglect }}: 249.96, \mathrm{Me}_{\text {perfect }}: 0.0\right.$, MRD: 8.72, $\left.P<0.01\right)$.

For big trees-similarly to the previous two tree size categories-soil seed bank density under honey locust tree canopies showed an increasing trend as park maintenance intensity decreased (Fig. 3c). A seed bank density of 23.8 seeds $/ \mathrm{m}^{2}$ was encountered in perfectly maintained parks while a somewhat higher value, 33.3 seeds $/ \mathrm{m}^{2}$, was found in moderately maintained parks, yet the difference did not prove significant in statistical test. The highest seed 

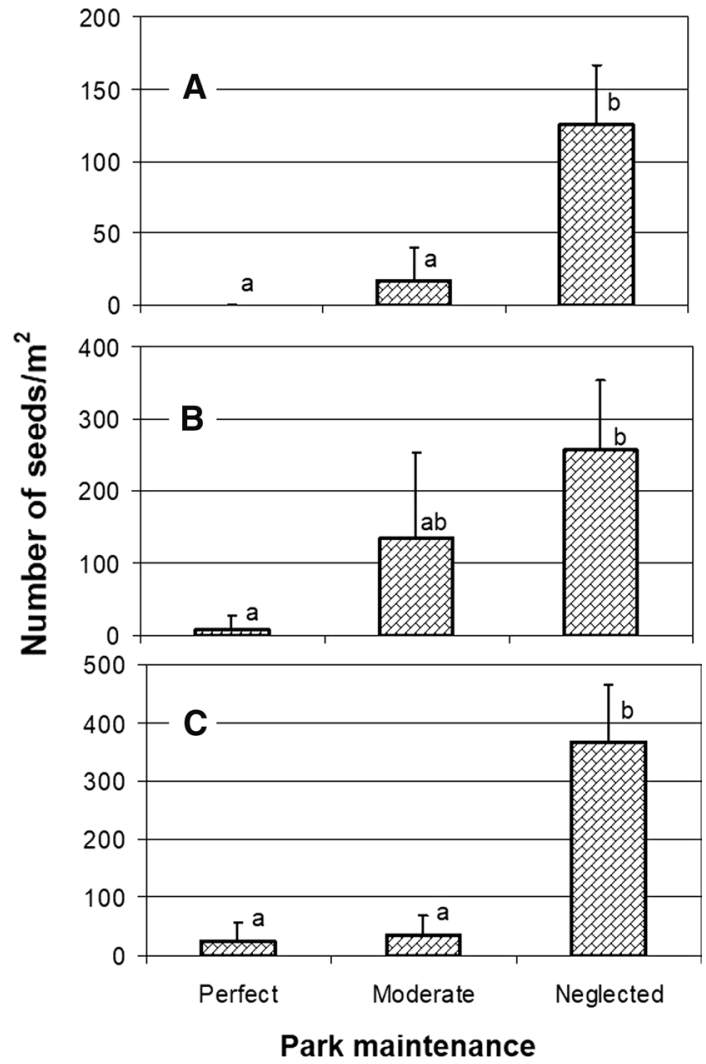

Fig. 3 Soil seed bank densities under the canopy of small-sized (a), medium-sized (b) and big-sized (c) honey locust trees found in urban parks of Budapest (Hungary) with different levels of park maintenance intensity

bank density, 366.6 seeds $/ \mathrm{m}^{2}$, was observed under big trees in neglected parks, and this was the highest value among all groups examined ("Appendix 2"). Moreover, it was significantly higher than the densities under big trees in moderately or perfectly maintained parks $\left(\mathrm{Me}_{\text {neglect }}: 374.94, \mathrm{Me}_{\text {moderate }}\right.$ : 41.66, MRD: $7.90, P<0.05$ and $\mathrm{Me}_{\text {neglect }}: 374.94, \mathrm{Me}_{\text {perfect }}$ : 0.0 , MRD: $8.93, P<0.01$, respectively).

When the influence of park maintenance intensity was considered for all trees irrespective of their size, the average seed bank densities for perfect, moderate and neglected park maintenance categories were $12.3,61.1$ and 250.0 seeds $/ \mathrm{m}^{2}$, respectively (Fig. 4). The statistical test showed a remarkably significant increase in seed bank density of neglected parks compared to the other two maintenance categories $\left(\mathrm{Me}_{\text {neglect }}: 229.13, \mathrm{Me}_{\text {moderate }}\right.$ : 41.66, MRD: $17.73, P<0.001$ and $\mathrm{Me}_{\text {neglect }}: 229.13, \mathrm{Me}_{\text {perfect }}: 0.0$, MRD: $\left.25.56, P<0.001\right)$.

For neglected parks, significant $\left(R^{2}=0.6142, P<0.0005\right)$ positive linear relationship was found between trunk circumference (independent variable) and soil seed bank density under canopy (dependent variable) of honey locust trees: seed bank density increased with increasing tree size (Fig. 5).

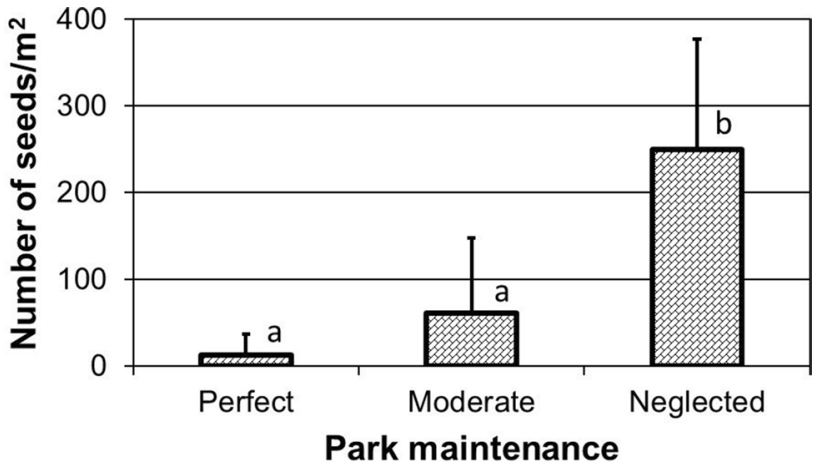

Fig. 4 Effect of park maintenance intensity on the soil seed bank density under the canopies of honey locust specimens irrespective to the tree size categories in urban parks of Budapest, Hungary

\section{Discussion}

Following mechanical scarification, we found $96.1 \%$ germination ratio for honey locust seeds. It is practically the same rate as it was found for this species after chemical scarification (Ferus et al. 2013; Kheloufi 2017) and is among the highest values published for a wide range of taxonomically related hardseeded species (Jones et al. 2016; Siles et al. 2016; Goets et al. 2018). It means that honey locust has a high seed viability that should be considered when assessing its invasiveness.

In the present study, seed bank densities varied between 0 and 500 seeds $/ \mathrm{m}^{2}$ under canopies of honey locust trees. In 17 out of 48 cases, the density was above 100 seeds $/ \mathrm{m}^{2}$. In a broader comparison, seed bank densities reported in this research are not outstanding since higher densities for certain plant species (including invasive ones) were often found in other studies (Wang et al. 2017; Goets et al. 2018).

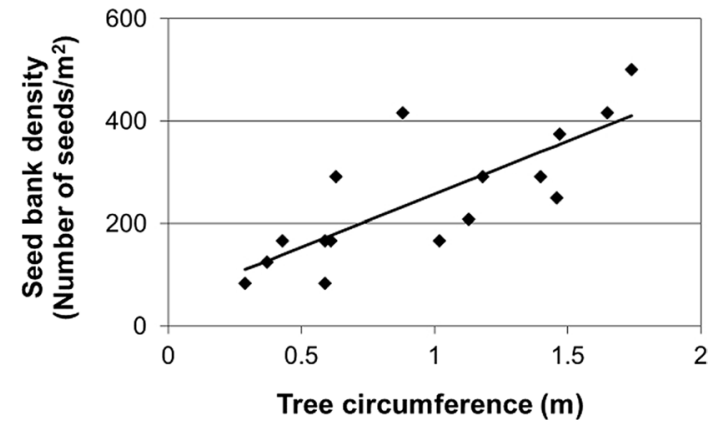

Fig. 5 Linear regression of soil seed bank density under tree canopies against tree trunk circumference of honey locust specimens $(n=16)$ in neglected parks in Budapest, Hungary

But regarding tree species, where seeds are often absent or in a low quantity in the soil seed bank (Honu and Dang 2002; 
Nano et al. 2013; Douh et al. 2018), the records for honey locust are still considerable.

Increasing density of soil seed bank under the canopy of woody species parallel with the age of the specimens is a plausible assumption, although rarely documented by published studies (but see Allen et al. 1995; Cseresnyés and Csontos 2012; Aguirre-Acosta et al. 2014). The accumulation of seed bank should be more pronounced for trees known about considerable survival of their seeds, retaining germinability for long periods in the soil, like the case of honey locust (Ferreras et al. 2015). In the present study, the influence of tree size on soil seed bank density was inconsistent. Under park maintenance of either moderate or perfect intensity, seed density did not correlate with tree circumference. Lack of correlation can be caused either by habitat effects on seed production of honey locust specimens, as it has already been described for other species (Rocha and Aguilar 2001; Aguirre-Acosta et al. 2014), or by the park maintenance itself. The latter seems to be the more obvious reason because in neglected parks, where more or less natural accumulation of soil seed bank could take place, significantly higher seed density was observed under big trees than under small ones, and also in the direct correlation between tree circumference and seed density we obtained positive and significant relationship in a linear regression test. Our assumption on tree size-dependent seed bank is thus only partially true because the size effect is considerably influenced by park maintenance activity.

Accordingly, in the comparisons based on park maintenance categories, significant differences in soil seed bank density occurred in each tree size categories, having always the highest densities in neglected parks. This trend was even more pronounced when all trees, irrespective of trunk circumference, were compared according to the park maintenance categories, and the differences were supported with high level of significance. This result is consistent with our hypothesis that park management intensity has a strong effect on the soil seed bank density of honey locust trees.

In evaluating the invasion risk of honey locust, the high capacity for forming soil seed bank demonstrated here must be considered. Species with well-developed soil seed banks are common among invasive plants (Gioria et al. 2012, 2019). Propagule pressure was also emphasized as a key factor of invasion for trees (Lamarque et al. 2011). Persistent soil seed bank-which is considered as a mode of dispersal over time (Grime 1989)—can easily provide such a continuous propagule pressure. For this, the hard-coated, long viable seeds of honey locust provide a typical example.
Additionally, Herron et al. (2007) state that a species is more likely become invasive in new localities, if (1) it has already become invasive in one region outside of its native range; and (2) if it has a large native latitudinal distribution range. The case of honey locust fulfills both of these requirements as being seriously invasive in Argentina (Fernandez et al. 2017), and having a natural range between latitudes $\mathrm{N} 26^{\circ}$ $41^{\prime}$ and $\mathrm{N} 43^{\circ} 31^{\prime}$ in North America (Estrada-Castillón et al. 2002).

Based on the facts mentioned above, honey locust must be considered as a potentially invasive species. Just because it has not yet become seriously invasive in Hungary, it does not mean that it will not become invasive in the future. Lengthy lag-phase has been described for several cases in biological invasions (Crooks and Soulé 1999; Aikio et al. 2010), and we will probably make the right decision regarding honey locust if we assume that we are now witnessing its extended lag-phase. Therefore, we need to consider appropriate methods to prevent honey locust invasion.

Within urban parks regular removal of litter (which includes leaves, twigs and pods) can provide a satisfactory prevention of invasion as it is demonstrated by our results. However, special attention should be made for the proper disposal of the litter containing reproductive propagules of honey locust. In case of improper treatment, e.g., simple displacement of litter from the park or private garden to a peripheral site, even if it is an official landfill site of the settlement, the translocated litter can become a new center of invasion. Plaza et al. (2018) completed a literature review of studies on the vegetation of waste sites and concluded that more than $95 \%$ of the species found in rubbish dumps or landfills have invasive character and eight of them are among the 100 worst invasive species in Europe. It is also emphasized that compost from these sites are now being used for soil improvement in agricultural practice, thus seeds of invasive species might be spread to distant locations.

Therefore, gathering of litter must be followed by proper composting techniques. For agricultural weeds, several experiments demonstrated that successful weed seed destruction can be achieved if properly established conditions (first of all temperature and moisture level) prevail during windrow composting (Tompkins et al. 1998; Eghball and Lesoing 2000). Nevertheless, significant differences between species in tolerance to temperature, moisture and composting time were also reported (Grundy et al. 1998), and it underlines the need of species specific experiments to reveal circumstances under which seeds of the invasive species lost viability. 


\section{Conclusion for future biology}

Examples for successful control of widely established invasive species are rare, although their eradication campaign may work if there is sufficient dedication and persistence, as it has already happened with honey locust in Australia (Csurhes 2004). However, as it is well known, preventing an invasion is much cheaper; therefore, future activities should be focused on prevention. Our findings highlight two kinds of threats. The first is the formation of long-term persistent soil seed bank under the canopy of planted honey locust trees. It can be prevented by perfect maintenance of parks that includes regular collection of fallen pods. The second threat is the mistreatment of litter containing seeds of honey locust. If honey locust's litter is removed in the simplest way into waste sites, and especially when it is deposited illegally in a nearby abandoned area, it involves a significant risk because the alien species can easily grow up on these sites and its established stands may become starting points for further spread (Rusterholz et al. 2012). A recent survey showed that the gardens of property owners who were moving from downtown to suburban areas, consist of predominantly exotic taxa (Ward and Amatangelo 2018). This trend is coupled with parallel shrinking of traditional gardening: the cultivation of fruit trees and vegetable gardens are in decline. Gaggini et al. (2017) demonstrated that the proximity of modern suburban gardens had positive effect on the species number and density of invasive plants in nearby forests. The risk of spread of invasive species is further enhanced by the urban sprawl-an increasingly prevalent process that is typical of modern cities-because it increases the urban edge, i.e., the zone where the city and nature are in contact. Therefore, ecologists must increase awareness of the general public and particularly the garden owners about the problems caused by invasive species in connection with illegal garden waste dumping (Rusterholz et al. 2012). Popularization and promotion of proper composting methods are also pivotal for the future maintenance of suburban gardens. Seeds of different species respond differently to the duration and method of composting; therefore, direct seed biological investigations are recommended for seeds of Gleditsia triacanthos, as well as for seeds of other alien species which tend to become invasive. Finally, it should be introduced as a rule that non-native species should only be planted in ornamental gardens, where aesthetic reasons make sense their use, while native species should be preferred in other urban green areas (e.g., tree alleys planted to reduce the noise associated with roadway traffic).

Acknowledgements Open access funding provided by Centre for Agricultural Research. The authors are grateful to the anonymous reviewers for their comments and suggestions. The authors thank support from the Hungarian National Science Fund (NKFI-OTKA-K128703). Moreover, TF gratefully acknowledge the funding received from Tempus Public Foundation within the frame of Stipendium Hungaricum Scholarship.

Authors' contributions PC, formulated the research concept, has leading role in planning and implementation, was engaged in field and laboratory work and participated in drafting the manuscript; TK added substantially to the planning and implementation of the research and participated in drafting the manuscript; TF carried out the majority of field and laboratory work and took part in data analysis and interpretation of results; AL was involved in the analysis of data; TH was engaged in the interpretation of results and in drafting the manuscript; JT participated in the analysis of data and interpretation of results.

Funding $\mathrm{PC}$ and $\mathrm{TH}$ received financial support from Hungarian National Science Fund (NKFI-OTKA-K128703), TF received Stipendium Hungaricum Scholarship from Tempus Public Foundation.

Data accessibility Data are included in the article's appendices. These appendices are given above the References.

\section{Compliance with ethical standards}

Conflict of interest The authors declare that they have no conflict of interest.

Open Access This article is licensed under a Creative Commons Attribution 4.0 International License, which permits use, sharing, adaptation, distribution and reproduction in any medium or format, as long as you give appropriate credit to the original author(s) and the source, provide a link to the Creative Commons licence, and indicate if changes were made. The images or other third party material in this article are included in the article's Creative Commons licence, unless indicated otherwise in a credit line to the material. If material is not included in the article's Creative Commons licence and your intended use is not permitted by statutory regulation or exceeds the permitted use, you will need to obtain permission directly from the copyright holder. To view a copy of this licence, visit http://creativecommons.org/licenses/by/4.0/.

\section{Appendices}


Appendix 1. Geographical location and soil seed bank data of sampled honey locust trees growing in urban parks of Budapest, Hungary

\begin{tabular}{|c|c|c|c|c|c|c|c|c|}
\hline Sample & GPS north & GPS east & Park treatment & Trunk size & Location & $\begin{array}{l}\text { No. of } \\
\text { seeds } \\
\text { found }\end{array}$ & $\begin{array}{l}\text { No. of seeds } \\
\text { germinated }\end{array}$ & $\begin{array}{l}\text { Seed bank } \\
\text { density (seeds/ } \\
\mathrm{m}^{2} \text { ) }\end{array}$ \\
\hline 1 & $47^{\circ} 28.838$ & $19^{\circ} 3.319$ & Perfect & Big & BME Campus & 0 & 0 & 0 \\
\hline 2 & $47^{\circ} 29.126$ & $19^{\circ} 2.893$ & Moderate & Medium & Gellért Hill & 1 & 1 & 41.66 \\
\hline 3 & $47^{\circ} 31.105$ & $19^{\circ} 4.754$ & Perfect & Big & Hősök tere area & 0 & 0 & 0 \\
\hline 4 & $47^{\circ} 31.879$ & $19^{\circ} 4.823$ & Perfect & Medium & Floridsdorf sétány & 0 & 0 & 0 \\
\hline 5 & $47^{\circ} 31.897$ & $19^{\circ} 4.813$ & Perfect & Medium & Floridsdorf sétány & 0 & 0 & 0 \\
\hline 6 & $47^{\circ} 32.843$ & $19^{\circ} 4.653$ & Perfect & Big & Tripolisz tér & 1 & 1 & 41.66 \\
\hline 7 & $47^{\circ} 32.814$ & $19^{\circ} 4.602$ & Perfect & Big & Tripolisz tér & 2 & 2 & 83.32 \\
\hline 8 & $47^{\circ} 28.672$ & $19^{\circ} 6.183$ & Neglected & Big & Népliget park & 7 & 7 & 291.62 \\
\hline 9 & $47^{\circ} 28.513$ & $19^{\circ} 6.427$ & Moderate & Big & Népliget park & 2 & 2 & 83.32 \\
\hline 10 & $47^{\circ} 28.564$ & $19^{\circ} 6.500$ & Neglected & Small & Népliget park & 3 & 3 & 124.98 \\
\hline 11 & $47^{\circ} 28.602$ & $19^{\circ} 6.557$ & Neglected & Big & Népliget park & 9 & 9 & 374.94 \\
\hline 12 & $47^{\circ} 28.635$ & $19^{\circ} 4.813$ & Neglected & Big & Haller utca & 7 & 6 & 249.96 \\
\hline 13 & $47^{\circ} 31.077$ & $19^{\circ} 4.803$ & Perfect & Big & Városliget city park & 1 & 1 & 41.66 \\
\hline 14 & $47^{\circ} 30.902$ & $19^{\circ} 5.126$ & Perfect & Big & Városliget city park & 0 & 0 & 0 \\
\hline 15 & $47^{\circ} 30.907$ & $19^{\circ} 5.122$ & Perfect & Big & Városliget city park & 0 & 0 & 0 \\
\hline 16 & $47^{\circ} 29.463$ & $19^{\circ} 2.445$ & Perfect & Medium & Esperanto park & 0 & 0 & 0 \\
\hline 17 & $47^{\circ} 29.630$ & $19^{\circ} 2.187$ & Perfect & Small & Esperanto park & 0 & 0 & 0 \\
\hline 18 & $47^{\circ} 32.728$ & $19^{\circ} 2.368$ & Neglected & Medium & Boldog Sándor István park & 5 & 4 & 166.64 \\
\hline 19 & $47^{\circ} 32.707$ & $19^{\circ} 2.359$ & Perfect & Medium & Boldog Sándor István park & 1 & 1 & 41.66 \\
\hline 20 & $47^{\circ} 32.711$ & $19^{\circ} 2.365$ & Moderate & Small & Boldog Sándor István park & 0 & 0 & 0 \\
\hline 21 & $47^{\circ} 27.967$ & $19^{\circ} 1.972$ & Moderate & Medium & Bikás Park & 0 & 0 & 0 \\
\hline 22 & $47^{\circ} 29.174$ & $19^{\circ} 5.618$ & Neglected & Medium & Golgota út & 10 & 10 & 416.6 \\
\hline 23 & $47^{\circ} 29.152$ & $19^{\circ} 5.708$ & Neglected & Medium & Golgota út & 7 & 7 & 291.62 \\
\hline 24 & $47^{\circ} 29.081$ & $19^{\circ} 5.588$ & Moderate & Small & Biró Lajos utca & 1 & 1 & 41.66 \\
\hline 25 & $47^{\circ} 28.971$ & $19^{\circ} 5.433$ & Moderate & Big & Orczy park & 0 & 0 & 0 \\
\hline 26 & $47^{\circ} 30.766$ & $19^{\circ} 0.694$ & Neglected & Medium & Herman Ottó utca & 6 & 5 & 208.3 \\
\hline 27 & $47^{\circ} 30.967$ & $19^{\circ} 12.523$ & Neglected & Small & Mátyásföld & 2 & 2 & 83.32 \\
\hline 28 & $47^{\circ} 30.574$ & $19^{\circ} 0.732$ & Neglected & Big & Szilágyi E. fasor & 13 & 12 & 499.92 \\
\hline 29 & $47^{\circ} 28.975$ & $19^{\circ} 5.104$ & Neglected & Small & Ludovika tér & 4 & 4 & 166.64 \\
\hline 30 & $47^{\circ} 29.086$ & $19^{\circ} 5.570$ & Neglected & Small & Orczy utca & 4 & 4 & 166.64 \\
\hline 31 & $47^{\circ} 29.110$ & $19^{\circ} 5.577$ & Neglected & Small & Orczy utca & 2 & 2 & 83.32 \\
\hline 32 & $47^{\circ} 29.176$ & $19^{\circ} 5.557$ & Neglected & Medium & Orczy utca & 7 & 7 & 291.62 \\
\hline 33 & $47^{\circ} 30.288$ & $19^{\circ} 8.987$ & Moderate & Medium & Kerepesi út & 5 & 5 & 208.3 \\
\hline 34 & $47^{\circ} 30.288$ & $19^{\circ} 8.988$ & Moderate & Small & Kerepesi út & 0 & 0 & 0 \\
\hline 35 & $47^{\circ} 30.277$ & $19^{\circ} 8.937$ & Moderate & Small & Kerepesi út & 1 & 1 & 41.66 \\
\hline 36 & $47^{\circ} 30.276$ & $19^{\circ} 8.902$ & Moderate & Medium & Kerepesi út & 7 & 7 & 291.62 \\
\hline 37 & $47^{\circ} 30.279$ & $19^{\circ} 8.965$ & Moderate & Medium & Kerepesi út & 3 & 3 & 124.98 \\
\hline 38 & $47^{\circ} 30.289$ & $19^{\circ} 8.915$ & Neglected & Medium & Kerepesi út & 5 & 4 & 166.64 \\
\hline 39 & $47^{\circ} 30.247$ & $19^{\circ} 8.485$ & Neglected & Big & Kerepesi út & 10 & 10 & 416.6 \\
\hline 40 & $47^{\circ} 30.259$ & $19^{\circ} 8.606$ & Perfect & Small & Kerepesi út & 0 & 0 & 0 \\
\hline 41 & $47^{\circ} 28.513$ & $19^{\circ} 4.744$ & Moderate & Big & Haller Park & 1 & 1 & 41.66 \\
\hline 42 & $47^{\circ} 28.492$ & $19^{\circ} 4.856$ & Moderate & Big & Haller Park & 1 & 1 & 41.66 \\
\hline 43 & $47^{\circ} 28.782$ & $19^{\circ} 4.238$ & Moderate & Big & Tinódi Park & 0 & 0 & 0 \\
\hline 44 & $47^{\circ} 28.844$ & $19^{\circ} 2.304$ & Perfect & Medium & Horticultural University & 0 & 0 & 0 \\
\hline 45 & $47^{\circ} 29.367$ & $19^{\circ} 4.485$ & Perfect & Small & Horváth Mihály tér & 0 & 0 & 0 \\
\hline 46 & $47^{\circ} 29.505$ & $19^{\circ} 4.767$ & Moderate & Small & Mátyás tér & 0 & 0 & 0 \\
\hline 47 & $47^{\circ} 29.475$ & $19^{\circ} 2.400$ & Perfect & Small & Kereszt utca & 0 & 0 & 0 \\
\hline 48 & $47^{\circ} 29.493$ & $19^{\circ} 2.468$ & Perfect & Small & Kereszt utca & 0 & 0 & 0 \\
\hline
\end{tabular}


undefined(continued)

\begin{tabular}{|c|c|c|c|c|c|c|c|c|}
\hline Sample & GPS north & GPS east & Park treatment & Trunk size & Location & $\begin{array}{l}\text { No. of } \\
\text { seeds } \\
\text { found }\end{array}$ & $\begin{array}{l}\text { No. of seeds } \\
\text { germinated }\end{array}$ & $\begin{array}{l}\text { Seed bank } \\
\text { density (seeds/ } \\
\mathrm{m}^{2} \text { ) }\end{array}$ \\
\hline$\overline{\text { Total nu }}$ & of seeds & d, ger & and a & $\mathrm{der}$ & & 128 & 123 & 106.75 \\
\hline
\end{tabular}

Appendix 2. Mean soil seed bank densities and standard deviations (SD) under the canopy of honey locust trees in urban parks of Budapest, Hungary, considering three groups of park management intensity (perfect, moderate and neglected) and three groups of tree size category (small: circumference $<0.60 \mathrm{~m}$, medium: cf. 0.61-1.20 m, and big: cf. $>1.20 \mathrm{~m}$ )

\begin{tabular}{|c|c|c|c|c|}
\hline & Perfect & Moderate & Neglect & Management types jointed \\
\hline \multirow[t]{6}{*}{ Small } & Mean value: 0 & Mean value: 16.66 & Mean value: 124.98 & Mean value: 47.21 \\
\hline & SD: 0 & SD: 22.82 & SD: 41.66 & SD: 62.72 \\
\hline & Min: 0.00 & Min: 0.00 & Min: 83.32 & Min: 0.00 \\
\hline & Median: 0.00 & Median: 0.00 & Median: 124.98 & Median: 0.00 \\
\hline & Max: 0.00 & Max: 41.66 & Max: 166.64 & Max: 166.64 \\
\hline & $n: 5$ & $n: 5$ & $n: 5$ & $n: 15$ \\
\hline \multirow[t]{6}{*}{ Medium } & Mean value: 8.33 & Mean value: 133.31 & Mean value: 256.90 & Mean value: 140.60 \\
\hline & SD: 18.63 & SD: 119.30 & SD: 96.51 & SD: 135.1 \\
\hline & Min: 0.00 & Min: 0.00 & Min: 166.64 & Min: 0.00 \\
\hline & Median: 0.00 & Median: 124.98 & Median: 249.96 & Median: 145.81 \\
\hline & Max: 41.66 & Max: 291.62 & Max: 416.60 & Max: 416.60 \\
\hline & $n: 5$ & $n: 5$ & $n: 6$ & $n: 16$ \\
\hline \multirow[t]{6}{*}{ Big } & Mean value: 23.81 & Mean value: 33.32 & Mean value: 366.61 & Mean value: 127.43 \\
\hline & SD: 32.78 & SD: 34.85 & SD: 99.46 & SD: 168.88 \\
\hline & Min: 0.00 & Min: 0.00 & Min: 249.96 & Min: 0.00 \\
\hline & Median: 0.00 & Median: 41.66 & Median: 374.94 & Median: 41.66 \\
\hline & Max: 83.32 & Max: 83.32 & Max: 499.92 & Max: 499.92 \\
\hline & $n: 7$ & $n: 5$ & $n: 5$ & $n: 17$ \\
\hline \multirow{6}{*}{$\begin{array}{l}\text { Tree size } \\
\text { categories } \\
\text { jointed }\end{array}$} & Mean value: 12.25 & Mean value: 61.10 & Mean value: 249.96 & \\
\hline & SD: 24.49 & SD: 86.05 & SD: 126.36 & \\
\hline & Min: 0.00 & Min: 0.00 & Min: 83.32 & \\
\hline & Median: 0.00 & Median: 41.66 & Median: 229.13 & \\
\hline & Max: 83.32 & Max: 291.62 & Max: 499.92 & \\
\hline & $n: 17$ & $n: 15$ & $n: 16$ & \\
\hline
\end{tabular}

$n$, number of sampled trees

\section{References}

Aguirre-Acosta N, Kowaljow E, Aguila R (2014) Reproductive performance of the invasive tree Ligustrum lucidum in a subtropical dry forest: does habitat fragmentation boost or limit invasion? Biol Invasions 16:1397-1410

Aikio S, Duncan RP, Hulme P (2010) Lag-phases in alien plant invasions: separating the facts from the artefacts. Oikos 119:370-378. https://doi.org/10.1111/j.1600-0706.2009.17963.x

Allen RB, Williams PA, Lee WG (1995) Seed bank accumulation of broom (Cytisus scoparius) in South Island. In: Proceedings of the forty eighth New Zealand plant protection conference, Angus Inn, Hastings, New Zealand, August 8-10, pp 276-280

Balogh L, Dancza I, Király G (2004) Actual list of neophytes in Hungary and their classification according to their success. In: Mihály B, Botta-Dukát Z (eds) Biological invasions in Hungary
— invasive plants. TermészetBÚVÁR Alapítvány Kiadó, Budapest, pp 61-92

Benčat F (1982) Atlas rozšírenia cudzokrajných drevín na Slovensku [Atlas of exotic tree species spreading in Slovakia]. Veda, Bratislava, $\mathrm{p} 368$

Blair RM (1990) Honey locust (Gleditsia triacanthos L). In: Burns RM, Honkala BH (eds) Silvics of North America, agriculture handbook, vol 2. Hardwoods. Dept. of Agriculture, Forest Service, Washington, DC, pp 358-364

Bolund P, Hunhammar S (1999) Ecosystem services in urban areas. Ecol Econ 29:293-301. https://doi.org/10.1016/S0921 -8009(99)00013-0

Bowler DE, Buyung-Ali L, Knight TM, Pullin AS (2010) Urban greening to cool towns and cities: a systematic review of the empirical evidence. Landsc Urban Plan 97:147-155. https://doi. org/10.1016/j.landurbplan.2010.05.006 
Brander LM, Koetse MJ (2011) The value of urban open space: metaanalyses of contingent valuation and hedonic pricing results. J Environ Manag 92:2763-2773

Buchel S, Frantzeskaki N (2015) Citizens' voice: a case study about perceived ecosystem services by urban park users in Rotterdam, the Netherlands. Ecosyst Serv 12(Spec. Iss.):169-177. https://doi. org/10.1016/j.ecoser.2014.11.014

Čeplová N, Lososová Z, Kalusová V (2017) Urban ornamental trees: a source of current invaders; a case study from a European City. Urban Ecosyst 20:1135-1140

Chiesura A (2004) The role of urban parks for the sustainable city. Landsc Urban Plan 68:129-138

Chmura D (2013) Impact of alien tree species Quercus rubra L. on understorey environment and flora: a study of the Silesian Upland (Southern Poland). Pol J Ecol 61:431-442

Crooks JA, Soulé ME (1999) Lag times in population explosions of invasive species: causes and implications. In: Sandlund OT, Schei PJ, Viken Á (eds) Invasive species and biodiversity management. Kluwer Academic Publishers, Dordrecht, pp 103-125

Cseresnyés I, Csontos P (2012) Soil seed bank of the invasive Robinia pseudoacacia in planted Pinus nigra stands. Acta Bot Croat 71:249-260. https://doi.org/10.2478/v10184-011-0065-2

Csurhes SM (2004) Successful control of honey locust trees (Gleditsia triacanthos L.) in Queensland. In: Sindel BM, Johnson SB (eds) Weed management: balancing people, planet, profit. 14th Australian weeds conference, Wagga Wagga, New South Wales, Australia, 6-9 September 2004, pp 673-675

Douh C, Daïnou K, Loumeto JJ, Moutsambote JM, Fayolle A, Tosso F, Forni E, Gourlet-Fleury S, Doucet JL (2018) Soil seed bank characteristics in two central African forest types and implications for forest restoration. For Ecol Manag 409:766-776

Early R, Bradley BA, Dukes JS, Lawler JJ, Olden JD, Blumenthal DM, Gonzalez P, Grosholz ED, Ibanez I, Miller LP, Sorte CJB, Tatem AJ (2016) Global threats from invasive alien species in the twentyfirst century and national response capacities. Nat Commun 7 , article number 12485. https://doi.org/10.1038/ncomms 12485

Eghball B, Lesoing GW (2000) Viability of weed seeds following manure windrow composting. Compost Sci Util 8:46-53. https:// doi.org/10.1080/1065657X.2000.10701749

Essl F (2007) From ornamental to detrimental? The incipient invasion of Central Europe by Paulownia tomentosa. Preslia 79:377-389

Estrada-Castillón E, Jurado E, Jiménez-Pérez J (2002) New locality of Gleditsia triacanthos (Caesalpiniaceae) in Northeastern Mexico and its phytogeographic interest. Southwest Nat 47:602-604. https ://doi.org/10.2307/3672664

Fernandez RD, Ceballos SJ, Malizia A, Aragon R (2017) Gleditsia triacanthos (Fabaceae) in Argentina: a review of its invasion. Aust J Bot 65:203-213

Ferreras AE, Funes G, Galetto L (2015) The role of seed germination in the invasion process of Honey locust (Gleditsia triacanthos L., Fabaceae): comparison with a native confamilial. Plant Spec Biol 30:126-136. https://doi.org/10.1111/1442-1984.12041

Ferus P, Barta M, Konôpková J, Turčeková S, Maňka P, Bibeň T (2013) Diversity in honey locust (Gleditsia triacanthos L.) seed traits across Danube basin. Folia Oecol 40:163-169

Gaggini L, Rusterholz H-P, Baur B (2017) Settlements as a source for the spread of non-native plants into Central European suburban forests. Acta Oecol 79:18-25

Gioria M, Pyšek P, Moravcová L (2012) Soil seed banks in plant invasions: promoting species invasiveness and long-term impact on plant community dynamics. Preslia 84:327-350

Gioria M, Le Roux JJ, Hirsch H, Moravcova L, Pyšek P (2019) Characteristics of the soil seed bank of invasive and non-invasive plants in their native and alien distribution range. Biol Invasions 21:2313-2332. https://doi.org/10.1007/s10530-019-01978-y
Glišić M, Lakušić D, Šinžar-Sekulić J, Jovanović S (2014) GIS analysis of spatial distribution of invasive tree species in the protected natural area of Mt. Avala (Serbia). Bot Serb 38:131-138

Glogov P, Pavlova D, Georgieva M, Dodev Y, Gyudorova S (2019) Survey of invasive alien species in the flora of Lozenska Mountain, Bulgaria. Bot Közlem 106:197-216

Goets SA, Kraaij T, Little KM (2018) Seed bank and growth comparisons of native (Virgilia divaricata) and invasive alien (Acacia mearnsii and A. melanoxylon) plants: implications for conservation. PeerJ 6:e5466. https://doi.org/10.7717/peerj.5466

GraphPad InStat (1998) version 3.06 for Windows 95. GraphPad Software, San Diego. https://www.graphpad.com/scientific-software/ instat/. Accessed 5 April 2020

Grime JP (1989) Seed banks in ecological perspective. In: Leck MA, Parker VT, Simpson RL (eds) Ecology of soil seed banks. Academic Press, San Diego, pp 15-22

Grundy AC, Green JM, Lennartsson M (1998) The effect of temperature on the viability of weed seeds in compost. Compos Sci Util 6:26-33. https://doi.org/10.1080/1065657X.1998.10701928

Herron PR, Martine CT, Latimer AM, Leicht-Young SA (2007) Invasive plants and their ecological strategies: prediction and explanation of woody plant invasion in New England. Divers Distrib 13:633-644

Hobbs RJ, Humphries SE (1995) An integrated approach to the ecology and management of plant invasions. Conserv Biol 9:761-770

Honu YAK, Dang QL (2002) Spatial distribution and species composition of tree seeds and seedlings under the canopy of the shrub, Chromolaena odorata Linn., in Ghana. For Ecol Manag 164:185-196

Jones CD, Stevens MR, Jolley VD, Hopkins BG, Jensen SL, Turner D, Stettler JM (2016) Evaluation of thermal, chemical, and mechanical seed scarification methods for 4 Great Basin lupine species. Nat Plants J 17:5-17

Kheloufi A (2017) Germination of seeds from two leguminous trees (Acacia karroo and Gleditsia triacanthos) following different pre-treatments. Seed Sci Technol 45:259-262. https://doi. org/10.15258/sst.2017.45.1.21

Kudoh H, Nakayama M, Lihova J, Marhold K (2007) Does invasion involve alternation of germination requirements? A comparative study between native and introduced strains of an annual Brassicaceae, Cardamine hirsuta. Ecol Res 22:869-875

Lamarque L, Delzon S, Lortie C (2011) Tree invasions: a comparative test of the dominant hypotheses and functional traits. Biol Invasions 13:1969-1989. https://doi.org/10.1007/s10530-011-0015-x

Muratet A, Pellegrini P, Dufour AB, Arrif T, Chiron F (2015) Perception and knowledge of plant diversity among urban park users. Landsc Urban Plan 137:95-106. https://doi.org/10.1016/j.landu rbplan.2015.01.003

Nano CEM, Bowland AE, Pavey CR (2013) Factors controlling regeneration in a rare desert tree Acacia peuce: limits to soil seed bank accumulation in time and space. J Arid Environ 90:114-122

Plaza PI, Speziale KL, Lambertucci SA (2018) Rubbish dumps as invasive plant epicentres. Biol Invasions 20:2277-2283

Pyšek P, Danihelka J, Sadlo J, Chrtek J, Chytry M, Jarosik V, Kaplan Z, Krahulec F, Moravcova L, Pergl J, Stajerova K, Tichy L (2012) Catalogue of alien plants of the Czech Republic (2nd edition): checklist update, taxonomic diversity and invasion patterns. Preslia 84:155-255

Richardson D, Pyšek P (2006) Plant invasions: merging the concepts of species invasiveness and community invasibility. Prog Phys Geog 30:409-431. https://doi.org/10.1191/0309133306pp490pr

Roberts HA (1981) Seed banks in soils. Adv Appl Biol 6:1-55

Rocha OJ, Aguilar G (2001) Reproductive biology of the dry forest tree Enterolobium cyclocarpum (guanacaste) in Costa Rica: a comparison between trees left in pastures and trees in continuous forst. Am J Bot 88:1607-1614. https://doi.org/10.2307/3558405 
Rusterholz H-P, Wirz D, Baur B (2012) Garden waste deposits as a source for non-native plants in mixed deciduous forests. Appl Veg Sci 15:329-337

Siles G, Torres JA, Ruiz-Valenzuela L, García-Fuentes A (2016) Germination trials of annual autochthonous leguminous species of interest for planting as herbaceous cover in olive groves. Agric Ecosyst Environ 217:119-127

Strydom M, Veldtman R, Ngwenya MZ, Esler KJ (2017) Invasive Australian Acacia seed banks: size and relationship with stem diameter in the presence of gall-forming biological control agents. PLoS ONE 12, article number: e0181763. https://doi.org/10.1371/ journal.pone. 0181763

Tognetti PM, Mazia N, Ibáñez G (2019) Seed local adaptation and seedling plasticity account for Gleditsia triacanthos tree invasion across biomes. Ann Bot 124:307-318. https://doi.org/10.1093/ aob/mcz077

Tompkins DK, Chaw D, Abiola AT (1998) Effect of windrow composting on weed seed germination and viability. Compos Sci Util 6:30-34. https://doi.org/10.1080/1065657X.1998.10701906

Wang N, Jiao J, Jia Y, Wang D (2017) Influence of afforestation on the species diversity of the soil seed bank and understory vegetation in the Hill-Gullied Loess Plateau, China. Int J Environ Res Public Health 14, article number: 1285. https://doi.org/10.3390/ ijerph14101285

Ward SG, Amatangelo KL (2018) Suburban gardening in Rochester, New York: exotic plant preference and risk of invasion. Landsc Urban Plan 180:161-165 